\title{
Response of Rice Yield and Soil to Sulfur Application under Water and Salinity Stresses
}

\author{
B.A.Zayed, M.S.M. Abdel-Aal ${ }^{* \#}$ and G.A Deweedar \\ Rice Research \& Training Center Sakha, Kafr El-Sheikh, Field Crop Research \\ Institute, Agricultural Research Center, Giza and ${ }^{*}$ Crop Science Dept., Fac Agric., \\ Menoufia University, Shebin El-Koom, Egypt.
}

\begin{abstract}
TWO FIELD experiments were conducted at El-Sirw Agricultural Research Station, Damietta Governorate, Egypt during summer seasons of 2015 and 2016 to investigate the effect of three irrigation intervals ( 3,6 and 9 days ) and four soil application of sulfur rates ( $0,200,400$ and $600 \mathrm{~kg} \mathrm{~S} / \mathrm{ha}$ ) and their interaction on the soil properties, growth characters, yield and yield components as well as water productivity of rice under saline soil conditions. In each experiment, strip plot design with four replications was used, where the horizontal plots were devoted to the irrigation intervals and the vertical plots were allocated by the sulfur rates. Irrigation every 3 days significantly decreased the values of the soil chemical properties studied, i.e. soil acidity $(\mathrm{pH})$, electrical conductivity $(\mathrm{EC})$ and bulk density but significantly increased growth characters, i.e. chlorophyll content, leaf area, dry matter production and number of tillers/ hill and plant height as well as yield and yield components, i.e. number of panicles/ hill, panicle length , panicle weight, number of filled grains/ panicle, fertility \% , 1000-grain weight, grain and biological yields/ ha and harvest index as compared with irrigation every 6 and 9 days. However, irrigation every 9 days significantly increased the number of unfilled grains/ panicle. Increasing soil application of sulfur rates up to $600 \mathrm{~kg} \mathrm{~S} /$ ha decreased the values of soil properties (pH , EC and bulk density) as well as significantly and gradually increased the aforementioned growth characters as well as yield and yield components but significantly decreased number of unfilled grains/ panicle. The interaction effect between irrigation intervals and sulfur application rates, indicate that grain and biological yields/ ha were increased by the application of sulfur rates up to $400 \mathrm{~kg} \mathrm{~S} / \mathrm{ha}$ under short irrigation interval (3 days) and up to $600 \mathrm{~kg} \mathrm{~S} /$ ha under medium and and long irrigation intervals ( 6 and 9 days). The irrigation of rice plants every 3 days consumed the largest amount of irrigation water, while prolonging the irrigation intervals up to 6 and 9 days led to a gradual decrease in the amount of irrigation water consumed by 12.99 and $37.31 \%$, respectively compared with the irrigation every 3 days. Irrigation of rice plants every 6 days with the application of sulfur at a rate of $600 \mathrm{~kg} \mathrm{~S} /$ ha produced the highest values of water productivity $\left(0.296 \mathrm{~kg} / \mathrm{m}^{3}\right.$ water $)$ as an average of both seasons, indicating to the beneficial effect of the application of sulfur for improving soil properties, growth, yield and yield components as well as water productivity especially under prolonged irrigation interval in saline soil condition.
\end{abstract}

Keywords: Salinity, Irrigation, Sulfur, Rice.

\section{Introduction}

Rice (Oryza sativa L.) is a major food crop for more than half of the world's population and consider one of the important food crops in Egypt next to wheat. Rice is reclaiming crop for saline and saline-sodic soils. Rice is sensitive to salinity at different growth stages (Zeng, 2004).
Salinity is a major environmental stress that drastically affects plants growth by creating low osmotic potential outside the plants (KhajehHosseini et al., 2003). Increasing salinity of agricultural land had a negative impact on food production. Enhancing tolerance to salinity stress in crop plants is necessary in order to increase productivity with limited water supplies and high salinity.

\footnotetext{
"Corresponding author email: moha3b3al@gmail.com

DOI :10.21608/agro.2017.1274.1067

C2017 National Information and Documentation Center (NIDOC)
} 
Irrigation practices under saline sodic is continuously recommended to leach salts from rice root zone area to ensure healthy growth. Furthermore, using poor quality water need specific management and over water as leaching requirement. El-Sharkawy et al. (2006) and Zayed et al. (2013) found that prolonging irrigation interval under such condition significantly increased soil salinization and subsequently reduced rice yield and its component. Therefore, they stated that shortened the period of irrigation interval in the terms of 4 day intervals must be improved under such condition

Nutrients deficiency is very common under salt stress owing to high $\mathrm{pH}$. nutrient deficiency limit productivity trends observed in rice growing countries (Zhu et al., 2004). Ahmed et al. (2016) suggested that the application of sulfur is an effective option in improving the chemical properties, like $\mathrm{pHs}$, electric conductivity (EC) and Sodium absorption rate (SAR) of salt affected soils by decreasing their values and subsequently yield attribute of rice crop. Application of S fertilizer in saline soils is a viable procedure to counteract uptake of unnecessary toxic elements $\left(\mathrm{Na}^{+}\right.$and $\left.\mathrm{Cl}^{-}\right)$, which encourage selectivity of $\mathrm{K} / \mathrm{Na}$ and ability of calcium ion to decrease the harmful impacts of sodium ions in plants (Zaman et al., 2002) .Sulfur is essential plant nutrients it consider a key enzymes and vitamins in the plant and is necessary for the formation of chlorophyll, it accumulates in dry matter basis by about 0.2 to $0.5 \%$ in plant tissue (Ali et al., 2008 and Mazhar et al., 2011). Sulfur deficient plants have also less resistance under stress conditions (Doberman \& Fairhurst, 2000). Sulfur deficiency has become widespread in many countries, many soils are declining their sulfur fertility due to an intensive agriculture using fertilizers highly enriched in NPK (Zhao et al., 1999). S-deficiency results in general inhibition of photosynthesis and protein synthesis (Dubousset et al., 2010). S-deficiency reduces chlorophyll and rubisco content, and provokes chlorosis of young leaves (Muneer et al., 2014). Sulfur application decreased the hazardous effect of salinity and had favorable effect on growth and nutrient contents of rice. Sulfur used as a soil amendments for enhancing the rice productivity (Helmy et al., 2013). The aim of this investigation was studied the effect of irrigation intervals and sulfur application on growth, yield and water productivity of rice under saline soil.

\section{Materials and Methods}

Two field experiments were conducted at ElSirw Agricultural Research Station, Damietta
Governorate, Egypt during summer seasons of 2015 and 2016 to investigate the effect of three irrigation intervals, i.e. 3 (contionous flooding), 6 and 9 days and four soil application of sulfur rates $(0,200$, 400 and $600 \mathrm{~kg} \mathrm{~S} / \mathrm{ha}$ ) and their interaction on the soil properties, growth characters, yield and yield components as well as water productivity of rice under saline soil conditions. In each experiment , strip plot design with four replications was used , where the horizontal plots (from north to south direction) were devoted to the irrigation intervals and the vertical plots (from east to west direction) were allocated by the sulfur rates. The experiment was done in different land in each year of the study. Soil samples were taken before land preparation at the depth of $0-15 \mathrm{~cm}$ from soil surface to soil chemical analysis. The experimental soil was salinity clay and the chemical analysis are presented in Table 1.

Rice grains (Sakha 106 cultivar) were sown in the nursery at a rate of $120 \mathrm{~kg}$ / ha on April $29^{\text {th }}$ in both seasons. All normal agricultural practices of growing rice plants in the nursery were applied during the two growing seaons. After 30 days from sowing, the seedlings were transplanted in the permanent plot at a rate of 3 seedlings/ hill 20 X $20 \mathrm{~cm}$ apart. At each vertical plot, sulfur fertilizer ( Agricultural sulfur 98 $\% \mathrm{~S}$ as super fine ) was soil applied at the same time of soil preparation before transplanting according to the tested sulfur rates. Each plot size was $10 \mathrm{~m}^{2}(2 \mathrm{~m}$ width X 5 m length) and fertilized with phosphorus fertilizer as calcium superphosphate $\left(15.5 \% \mathrm{P}_{2} \mathrm{O}_{5}\right)$ at a rate of $37 \mathrm{~kg} \mathrm{P}_{2} \mathrm{O}_{5} \mathrm{~kg}$ / ha and added during land preparation. The potassium fertilizer as potassium sulphate $\left(48 \% \mathrm{~K}_{2} \mathrm{O}\right)$ was added at a rate of $50 \mathrm{~kg}$ $\mathrm{K}_{2} \mathrm{O} /$ ha at two doses, one of them was added at land preparation and the other one at the panicle initiation. Nitrogen fertilizer as urea $(46.5 \% \mathrm{~N})$ was applied at a rate of $160 \mathrm{~kg} \mathrm{~N} /$ ha in three doses, i.e. 15,30 and 45 days after transplanting. Zinc fertilizer at a rate of $24 \mathrm{~kg}$ zinc sulphate was manually broadcasted at the beginning of flooding. The weeds were controlled chemically using Saturn $50 \%$ at 7.5 litre/ ha four days after transplanting. Each horizontal plot was tightly surrounded by deep ditches with $2 \mathrm{~m}$ width and $1 \mathrm{~m}$ depth to isolate each other and irrigated according to the tested aforementioned irrigation intervals.

\section{Characters studied \\ Growth characters}

At heading stage, plant samples from each plot were taken to estimate :

1- Colorophyll content (SPAD value) according to

Yoshida et al. (1972)

2- Leaf area/ hill $\left(\mathrm{cm}^{2}\right)$

3- Dry matter production (g/hill) 
4- Plant height $(\mathrm{cm})$

5- Number of tillers/ hill

\section{Yield and yield components}

At harvest (130 days after sowing), ten plants from each plot were counted to determine:

1- Number of panicles/hill

2- Panicle length $(\mathrm{cm})$

3- No. of filled grains/ panicle unfilled

4- No. of unfilled grains/ panicle

5 - Fertility \%: it was determined by the following fomula

Fertility $\%=$

No. of filled grains/ panicle

No. of total spikelets/ panicle X 100

6- 1000- grain weight (g)

7- Panicle weight (g)

The plants in the central six rows at $10 \mathrm{~m}^{2}$ of each plot were harvested, dried and threshed to determine :

8- Grain yield (ton/ ha)

9- Biological yield (grain + straw) (ton/ ha)

10- Harvest index $=$

Grain yield/ ha Biological yield/ ha X 100

\section{Soil properties}

Also, After rice harvest, soil acidity $(\mathrm{pH})$ and electrical conductivity (EC) was determined according to the methods described by Page et al. (1982) as well as bulk density according to the methods described by Black et al. (1965).

Water requirement and productivity

The following water measurements were determined

1- Total applied water $\left(\mathrm{m}^{3} / \mathrm{ha}\right)$ :- Water pump provided with calibrate water meter was used for irrigation and calculation the total water used.

2- Saved water $\%=$

Water of irrigation every 3 days - water

of irrigation every 6 or 9 days X 100

Water of irrigation every 3 days

3- Water productivity ( $\mathrm{kg}$ grains/ $\mathrm{m}^{3}$ water) was calculated using the following Equation (Michael, 1978)

Water productivity $=$ Grain yield $(\mathrm{kg} / \mathrm{ha})$

Total applied water $\left(\mathrm{m}^{3} / \mathrm{ha}\right)$

All data collected were subjected to standard statistical analysis following the proceeding described by Gomes \& Gomez (1984) using the computer program (COSTAT). The treatment means were compared using Duncan's multiple range test Duncan (1955). * and ** symbol used in all Tables indicate the significant at 5\% and $1 \%$ levels of probability, respectively, while, NS means not significant.

\section{Results and Discussion}

\section{Soil properties}

The data of soil properties studied, i.e. soil acidity $(\mathrm{pH})$, electrical conductivity (EC) and bulk density of soil cultivated by rice as affected by irrigation intervals (3,6 and 9 days), the application of sulfur rates $(0,200,400$ and $600 \mathrm{~kg} \mathrm{~S} / \mathrm{ha})$ and their interaction in 2015 and 2016 seasons are presented in Table 2.

The data show that shortining irrigation intervals from 9 up to 3 days significantly decreased the values of $\mathrm{pH}, \mathrm{EC}$ and bulk density of the soil in both seasons. These results indicate that the irrigation interval may be ensured sufficient water addition to the soil which caused high effective leaching of sodium element (Na) from soil to drainage water and consequently improved the soil properties studied. On the other hand, the prolonging irrigation intervals show the opposite pattern . Similar results were obtained by El-Sharkawy et al. (2006).

Application of $600 \mathrm{~kg} \mathrm{~S} / \mathrm{ha}$ significantly decreased the values of $\mathrm{pH}$ and $\mathrm{EC}$ as shown in Tables 1 and 2 as well as bulk density as shown in Table 2 compared to unfertilized plants (Zero kg S/ ha ) in the two seasons. The reducing of $\mathrm{pH}$ soil by the sulfur application may be due its undergo oxidation to sulfuric acid which in turn reacts with limepresent in the soil to soluble calcium form which remove $\mathrm{Na}^{+}$ from soil absorption complex leading to reduce bulk density in improving soil aggregates and drainage system against soil depression. Similar results were obtained by Helmy et al. (2013).

With regard to the interaction effect between irrigation intervals and sulfur application rates, the differences among interaction treatments were not great enough to reach the $5 \%$ level of significance for the three soil properties studied in both seasons.

\section{Growth characters}

The data presented in Table 3 show the effect of irrigation intervals, sulfur application rates and their interaction on growth characters studied, i.e. total chlorophyll content, leaf area/ hill and dry matter/ hill, plant height and number of tillers / hill in 2015 and 2016 seasons. 
TABLE 1. Soil chemical properties of experimental soils in 2015 and 2016 seasons.

\begin{tabular}{|c|c|c|c|c|c|c|c|c|c|}
\hline \multirow[b]{2}{*}{ Season } & \multirow[b]{2}{*}{ pH } & \multirow{2}{*}{$\begin{array}{l}\text { ECe dS } \\
\mathbf{m}^{-1}\end{array}$} & \multicolumn{4}{|c|}{ Cation meqL $\mathrm{L}^{-1}$} & \multicolumn{3}{|c|}{ Anion meq $\mathrm{L}^{-1}$} \\
\hline & & & $\mathrm{Ca}^{+2}$ & $\mathbf{M g}^{+2}$ & $\mathbf{N a}^{+}$ & $\mathbf{K}+$ & $\mathrm{SO}^{-2}$ & $\mathbf{C L}^{-}$ & $\mathrm{HCO}^{-3}$ \\
\hline 2015 & 8.5 & 7.1 & 19.9 & 17.9 & 38.1 & 0.31 & 32.1 & 40.1 & 11.1 \\
\hline 2016 & 8.54 & 7.0 & 21.0 & 17.1 & 37.1 & 0.32 & 30.1 & 43.1 & 12.1 \\
\hline
\end{tabular}

TABLE2. Effect of irrigation intervals, sulfur rates and their interaction on pH, EC and bulk density of soil during 2015 and 2016 seasons.

\begin{tabular}{|c|c|c|c|c|c|c|}
\hline & \multicolumn{2}{|c|}{ pH } & \multicolumn{2}{|c|}{$\begin{array}{c}\mathrm{EC} \\
(\mathrm{dS} / \mathrm{m})\end{array}$} & \multicolumn{2}{|c|}{$\begin{array}{c}\text { Bulk density } \\
\left(\mathrm{g} / \mathrm{cm}^{3}\right)\end{array}$} \\
\hline & 2015 & 2016 & 2015 & 2016 & 2015 & 2016 \\
\hline \multicolumn{7}{|c|}{ Irrigation intervals (days) } \\
\hline 3 & 7.90 & 7.92 & 5.51 & 5.42 & 1.66 & 1.64 \\
\hline 6 & 8.22 & 8.13 & 6.21 & 6.02 & 1.71 & 1.68 \\
\hline 9 & 8.37 & 8.36 & 8.42 & $8 . .53$ & 1.75 & 1.76 \\
\hline F test & $* *$ & $* *$ & $* *$ & $* *$ & $* *$ & $*$ \\
\hline LSD at 0.05 & 0.005 & 0.008 & 1.01 & 1.20 & 0.02 & 0.01 \\
\hline Sulfur rates $(\mathrm{kg} \mathrm{S}$ & 846 & 8.50 & 822 & 833 & 177 & 176 \\
\hline 200 & 8.25 & 8.30 & 7.11 & 7.00 & 1.74 & 1.72 \\
\hline 400 & 8.03 & 8.14 & 6.31 & 6.20 & 1.68 & 1.68 \\
\hline 600 & 7.83 & 7.81 & 5.21 & 5.02 & 1.64 & 1.62 \\
\hline F test & $* *$ & $* *$ & $* *$ & $* *$ & $* *$ & $* *$ \\
\hline LSD at 0.05 & 0.003 & 0.01 & 0.9 & 1.0 & 0.01 & 0.01 \\
\hline Interaction & NS & NS & NS & NS & NS & NS \\
\hline
\end{tabular}

The data indicate that the highest significant values of all growth characters studied herein were get when the plants were irrigated by the shortest period of irrigation interval (3 days) followed by medium irrigation interval (6 days) without significant differences between them for leaf area/ hill ( in the first season ), plant height and no. of tillers/ hill (in the second season) and dry matter/ hill (in both seasons). However, the lowest significant values of the abovementioned growth characters were obtained by the largest period of irrigation interval (9 days) in both seasons. The depression in the growth of rice plants by prolonging irrigation interval (water stress) may be due to the reduction of plant capacity in building metabolites owing to reduce leaf expansion and total chlorophyll and consequently the photosynthetic efficiency. The harmful effect of water stress on the growth of rice plants are in harmony with the results obtained previously by El-Refaee et al. (2012), Ghazy (2015) and Ibrahim et al. (2017).

The data revealed that increasing sulfur application rates from 0 up to $600 \mathrm{~kg} \mathrm{~S}$ / ha gradually and significantly increased all growth characters studied in both seasons. There are no significant differences betweem the two rates of 400 and 600 $\mathrm{kg} \mathrm{S} /$ ha for total chlorophyll content, leaf area/ hill and no.of tillers/ hill in the first season as well as dry matter production / hill and plant height in the second season.

The enhancing of growth character obtained herein may be due to improve chemical properties of saline soil owing to sulfur application as previously discussed. These finding are in agreement with those obtained by Kineber et al. (2004), El-Eweddy et al. (2005) and Mazhar et al. (2011).

The interaction between irrigation intervals and sulfur rates had significant effect on no. of tillers / hill in both seasons (Table 3). However, the other growth characters were not significantly affected by that interaction in the first and / or second seasons. The data in Fig. 1 show that the highest numbers of tiller / hill (18.68 and 18.49) were obtained by the application of highest sulfur rate $(600 \mathrm{~kg} \mathrm{~S} /$ ha) under shortest period of irrigation intervals (3 days) in both seasons. On the other hand, the plants irrigated every 9 days and untreated with sulfur produced the lowest values (10.11 and 10.00 tillers/ hill ) in the first and second season, respectively.

\section{Yield and yield component}

The effect irrigation intervals and sulfur rates and their interaction on yield components, i.e. no. of panicles/ hill, panicle length , no. of grains/ panicle (filled and unfilled grain), fertility \% , 1000- grain weight and panicle weight are presented in Table 4. 

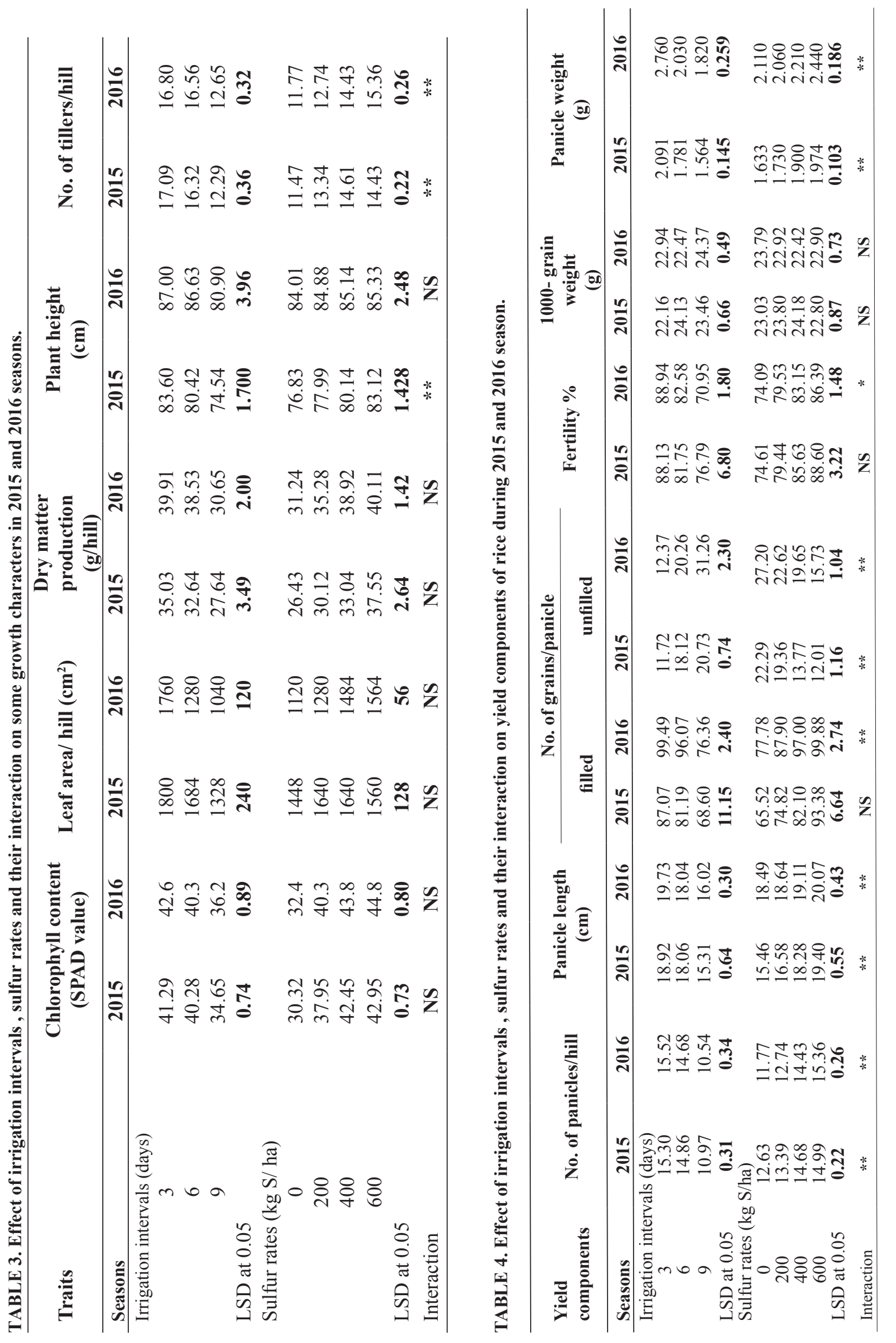

Egypt.J.Agron. Vol.39, No.3(2017) 

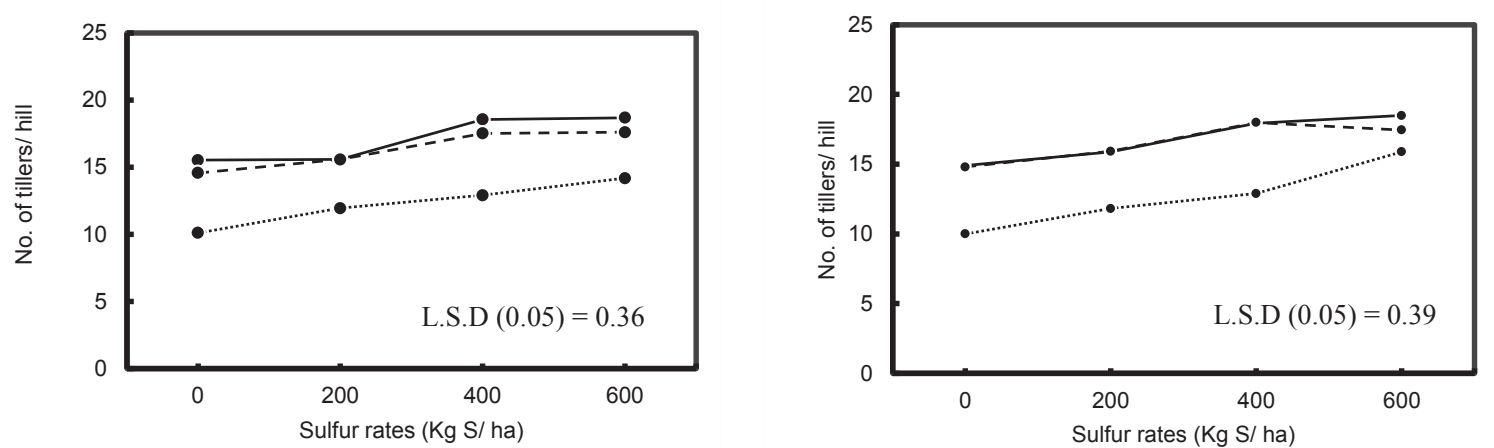

Fig. 1. Effect of the interaction between irrigation intervals and sulfur rates on the number of tillers /hill during 2015 and 2016 seasons. (Irrigation intervals 6 ----- , , $3-\bullet_{-}$and 9 days

The data indicated that the plants irrigated with shortest irrigation intervals (3 days) significantly increased no. of panicles/ hill, panicle length, no. of filled grains/ panicle, fertility \% , 1000- grain weight and panicle weight. On the other hand, prolonged irrigation intervals (9 days) significantly decreased in the abovementioned yield components but increase the unfilled grain/ panicle in the two seasons. The depression in the values of yield components obtained under water stress condition may be due to the decrease in the dry matter production as previously discussed as well as due to the decrease in the germinated pollen on stigmas resulted in flower sterility and this in turn decrease the fertility $\%$ and consequently increase unfilled grains / panicle . Similar finding were obtained by Rang et al. (2011).

Among the sulfur rates, the data show that the application of of $600 \mathrm{~kg} \mathrm{~S} /$ ha produced the highest significant values of no. of panicles/ hill, panicle length, no. of filled grains/ panicle, fertility \% , 1000grain weight and panicle weight but the lowest values of unfilled grains / panicle as compared with the other tested sulfur rates $(0,200$ and $400 \mathrm{~kg} \mathrm{~S} / \mathrm{ha})$ in both seasons. The superiority of most yield components obtained herein owing to sulfur application may be due to its effect on improving the soil properties and enhancing growth characters as previously discussed.

The interaction between irrigation intervals and sulfur rates had significant effects on the number of panicles/ hill, panicle length, panicle weight and unfilled grain/ panicle in the two seasons (Table 4). The data illustrated in Fig. 2 show that the highest values of number of panicle/ hill, panicle length and weight were obtained when the rice plants were irrigated every 3 days and applied with $600 \mathrm{~kg}$ S/ha in both seasons. Reversly, the plants irrigated every 9 days without sulfur application produced the highest values of unfilled grains/ panicle. This trend was fairly true in the two seasons. However, the other yield components were not significantly affected by that interaction in the first and/ or second season, therefore their data were neglected .

\section{Yield performance}

Table 5 included the data of grain and biogical yields/ ha as well as harvest index as affected by irrigation intervals, sulfur rates and their interaction in 2015 and 2016 seasons.

The data show that shortening irrigation intervals from 9 to 6 and 3 days caused a significant increasing in each of grain and biological yield/ ha as well as harvest index. This increase amounted to $(9.80$ and $61.70 \%)$ for grain yield/ ha , (2.67 and $38.90 \%)$ for biological yield/ ha and (6.96 and $16.45 \%$ ) for harvest index when the plants were irrigated every 3 days compared to when those irrigated every 6 and 9 days, respectively (as an average of the two seasons). This superiority may be due to the shortest irrigation intervals (3 days) mitigated the harmful effect of soil salinity in that experiments (Table 2) and consequently improved growth characters (Table 3) and yield component, i.e. no. of panicles/ hill , panicle length, no. of filled grains/ panicle, fertility $\%, 1000$ - grain weight and panicle weight (Table 4) and this in turn improved grain and biological yields/ ha. Moreover, it can be noticed that also that there are a sharply and dratistically reduction in grain and biological yields/ ha as well as harvest index when the plants were irrigated every 9 days more than those irrigated every 6 days. 
2015 Season
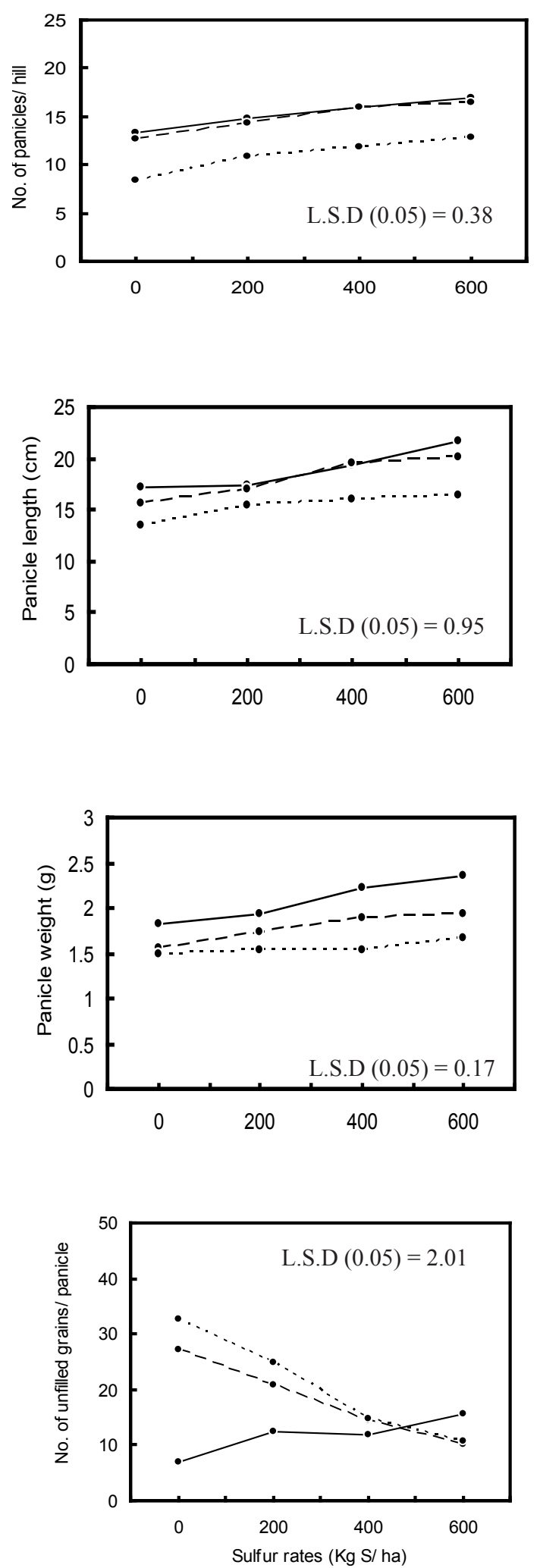

2016 Season
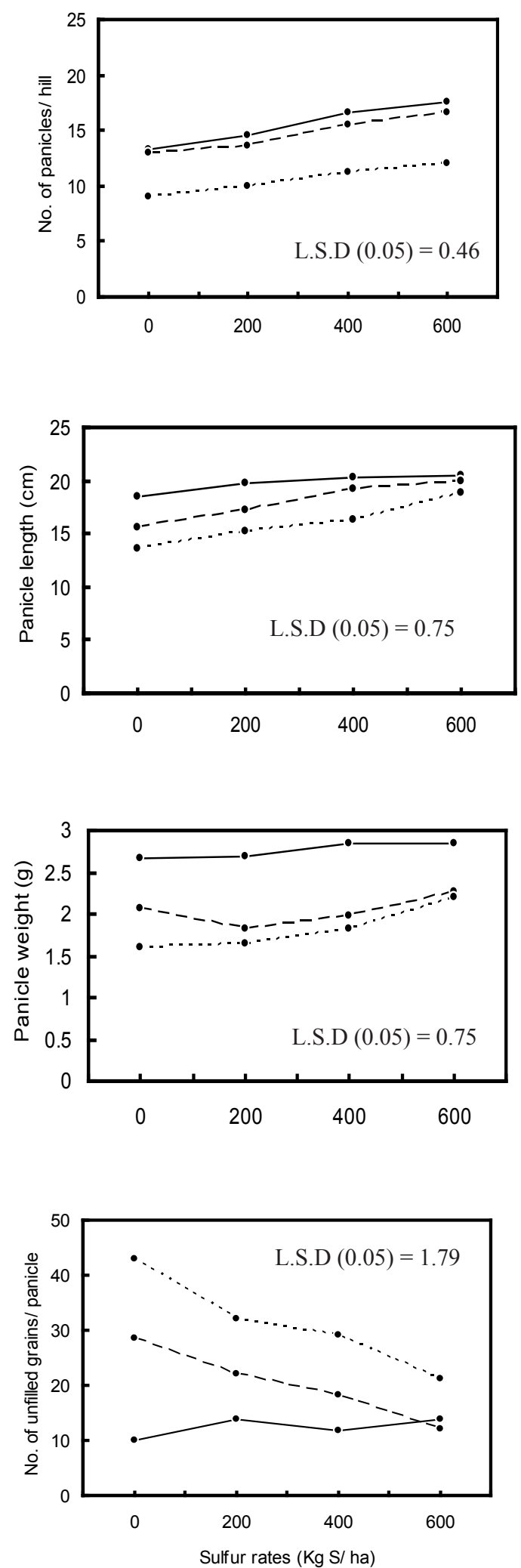

Fig. 2. Effect of the interaction between irrigation intervals and sulfur rates on some yield components of rice during 2015 and 2016 seasons. (Irrigation intervals $6--\bullet_{--}, 3-\bullet-$ and ... ... 9 days) 
TABLE 5. Effect of irrigation intervals, sulfur rates and their interaction on grain and biological yields/ ha as well as harvest index \% of rice during 2015 and 2016 seasons.

\begin{tabular}{ccccccc}
\hline \multirow{2}{*}{$\begin{array}{c}\text { Characters } \\
\text { (ton/ ha) }\end{array}$} & \multicolumn{2}{c}{$\begin{array}{c}\text { Biological yield } \\
\text { (ton/ ha) }\end{array}$} & \multicolumn{2}{c}{ Harvest index } \\
\hline Seasons & $\mathbf{2 0 1 5}$ & $\mathbf{2 0 1 6}$ & $\mathbf{2 0 1 5}$ & $\mathbf{2 0 1 6}$ & $\mathbf{2 0 1 5}$ & $\mathbf{2 0 1 6}$ \\
\hline Irrigation intervals (days) & & & & & & \\
3 & 4.10 & 4.30 & 9.04 & 9.10 & 45.35 & 47.25 \\
6 & 3.73 & 3.92 & 8.91 & 8.76 & 41.86 & 44.75 \\
9 & 2.43 & 2.78 & 6.56 & 6.50 & 37.04 & 42.77 \\
LSD at 0.05 & $\mathbf{0 . 3 2}$ & $\mathbf{0 . 3 5}$ & $\mathbf{0 . 4 5}$ & $\mathbf{0 . 4 3}$ & $\mathbf{3 . 0 0}$ & $\mathbf{1 . 9 0}$ \\
Sulfur rates (kg S/ha) & & & & & & \\
0 & 2.86 & 2.95 & 7.28 & 7.03 & 39.29 & 41.96 \\
200 & 3.27 & 3.44 & 8.07 & 7.64 & 40.52 & 45.03 \\
400 & 3.66 & 4.00 & 8.51 & 8.72 & 42.30 & 45.87 \\
600 & 3.83 & 4.19 & 8.86 & 9.07 & 43.23 & 46.20 \\
LSD at 0.05 & $\mathbf{0 . 2 2}$ & $\mathbf{0 . 2 4}$ & $\mathbf{0 . 3 1}$ & $\mathbf{0 . 4 2}$ & $\mathbf{1 . 3 0}$ & $\mathbf{0 . 9 0}$ \\
Interaction & $* *$ & $* *$ & $* *$ & $* *$ & NS & $\mathbf{N S}$ \\
\hline
\end{tabular}

The data show that the application of sulfur at a rate of $600 \mathrm{~kg} \mathrm{~S} /$ ha produced the maximum values of grain yield (3.83 and 4.19 ton/ ha), biological yield ( 8.86 and $9.07 \mathrm{ton} / \mathrm{ha}$ ) and harvest index (43.23 and 46.20\%) in the first and second seasons, respectively. However, it can be noticed that there are not significant differences between 400 and 600 $\mathrm{kg} \mathrm{S} /$ ha for grain yield/ ha and harvest index in both seasons. The superiority of grain and biological yields/ ha as well as harvest index by the application of sulfur may be due to its effect on reducing soil $\mathrm{pH}$ and improving soil structure as well as beneficial role in plant metabolism and consequently increase the yield components as previously discussed (Table 4). Similar results were observed by Lunde et al. (2008).

The interaction between irrigation intervals and sulfur rates were significant on grain and biological yields/ ha in the two seasons as shown in Table 6. However, harvest index was not significantly affected by such interaction in both seasons. The data show that increasing sulfur application rates gradually increased the values of grain and biological yields/ ha up to $400 \mathrm{~kg} \mathrm{~S} /$ ha under irrigation every 3 days and up to $600 \mathrm{~kg} \mathrm{~S} /$ ha under irrigation every 6 and 9 days. Moreover, it can be noticed that the sulfur application under the stress conditions (irrigation every 9 days) was more effective and pronounced for enhancing the increase percentage of grain and biological yields/ ha than that under the normal conditions (irrigation every 3 days).

Water applied and productivity

The data in Table 7 show that the plants irrigated every 3 days received the highest amounts of total water (14555 and $15185 \mathrm{~m}^{3} / \mathrm{ha}$ ) in both seasons. Moreover, it can be noticed that the total water applied was decreased and saved with increasing irrigation intervals from 3 to 6 days by about 1610 and $2265 \mathrm{~m}^{3}$ / ha (11.06 and $\left.14.92 \%\right)$ as well as from 3 to 9 days by about 5215 and $9295 \mathrm{~m}^{3} /$ ha (35.82 and $38.79 \%)$ in the first and second season, respectively. Similar results were nearly obtained by El-Refaee et al. (2012) and Ibrahim et al. (2017).

Data presented in Table 8 show that the values of water productivity was increased by increasing irrigation intervals up to 6 days $(0.288$ and $0.303 \mathrm{~kg}$ grains $/ \mathrm{m}^{3}$ ) and also by increasing sulfur rates up to $600 \mathrm{~kg} \mathrm{~S} / \mathrm{ha}\left(0.320\right.$ and $0.350 \mathrm{~kg}$ grains $\left./ \mathrm{m}^{3}\right)$ in the first and second season, respectively. Moreover, the interaction effect between irrigation intervals and sulfur rates indicate that the highest values of water productivity $\left(0.334\right.$ and $0.391 \mathrm{~kg}$ grains $\left./ \mathrm{m}^{3}\right)$ were obtained when the rice plants were irrigated every 9 days and fertilized with $600 \mathrm{~kg} \mathrm{~S} /$ ha in the two seasons. This means that the application of sulfur to rice plants cultivated in salinity soil raised the water productivity particulary when the plants were irrigated every 9 days . Similar results were obtained by Helmy et al. (2013). 
TABLE 6. The interaction between irrigation intervals and sulfur rates on grain and biological yields during 2015 and 2016 seasons

\begin{tabular}{|c|c|c|c|c|c|c|c|c|c|}
\hline \multirow{3}{*}{$\begin{array}{l}\text { Irrigation } \\
\text { intervals }\end{array}$} & \multirow{3}{*}{$\begin{array}{c}\text { Sulfur } \\
\text { rates } \\
\text { (kg S/ } \\
\text { ha) }\end{array}$} & \multicolumn{4}{|c|}{ Grain yield } & \multicolumn{4}{|c|}{ Biological yield } \\
\hline & & \multicolumn{2}{|c|}{ ton / ha } & \multicolumn{2}{|c|}{ Increase \% } & \multicolumn{2}{|c|}{ ton / ha } & \multicolumn{2}{|c|}{ Increase \% } \\
\hline & & 2015 & 2016 & 2015 & 2016 & 2015 & 2016 & 2015 & 2016 \\
\hline \multirow[t]{4}{*}{3 days } & 0 & 3.56 & 3.63 & - & - & 8.57 & 7.97 & - & - \\
\hline & 200 & 3.96 & 4.11 & 11.24 & 13.22 & 8.97 & 8.55 & 4.67 & 7.28 \\
\hline & 400 & 4.54 & 4.82 & 27.53 & 32.78 & 9.37 & 9.96 & 9.33 & 24.97 \\
\hline & 600 & 4.35 & 4.65 & 22.19 & 28.10 & 9.35 & 9.89 & 9.10 & 24.09 \\
\hline \multirow[t]{4}{*}{6 days } & 0 & 3.20 & 3.29 & - & - & 8.19 & 7.73 & - & - \\
\hline & 200 & 3.57 & 3.76 & 11.56 & 14.29 & 8.92 & 8.23 & 8.91 & 6.47 \\
\hline & 400 & 3.94 & 4.07 & 23.13 & 23.71 & 9.05 & 9.34 & 10.50 & 20.83 \\
\hline & 600 & 4.22 & 4.56 & 31.88 & 38.60 & 9.49 & 9.72 & 15.87 & 25.74 \\
\hline \multirow[t]{4}{*}{9 days } & 0 & 1.82 & 1.94 & - & - & 5.08 & 5.40 & - & - \\
\hline & 200 & 2.28 & 2.45 & 25.27 & 26.29 & 6.31 & 6.14 & 24.21 & 13.70 \\
\hline & 400 & 2.50 & 3.11 & 37.63 & 60.31 & 7.11 & 6.95 & 39.96 & 28.70 \\
\hline & 600 & 3.12 & 3.63 & 71.42 & 87.11 & 7.74 & 7.51 & 52.36 & 39.07 \\
\hline L.S.D at 0.05 & & 0.30 & 0.41 & - & - & 0.44 & 0.40 & - & - \\
\hline
\end{tabular}

TABLE 7. Effect of irrigation intervals on the amounts of total applied and saved water $\left(\mathrm{m}^{3} / \mathrm{ha}\right)$ during 2015 and 2016 seasons.

\begin{tabular}{|c|c|c|c|c|c|c|}
\hline \multirow{3}{*}{$\begin{array}{l}\text { Irrigation } \\
\text { interval } \\
\text { (days) }\end{array}$} & \multicolumn{3}{|c|}{2015 season } & \multicolumn{3}{|c|}{2016 season } \\
\hline & \multirow{2}{*}{$\begin{array}{c}\text { Applied water } \\
\left(\mathrm{m}^{3} / \mathbf{h a}\right)\end{array}$} & \multicolumn{2}{|c|}{ Saved water } & \multirow{2}{*}{$\begin{array}{l}\text { Applied } \\
\text { water } \\
\left(\mathrm{m}^{3} / \mathbf{h a}\right)\end{array}$} & \multicolumn{2}{|c|}{ Saved water } \\
\hline & & $\left(\mathrm{m}^{3} / \mathrm{ha}\right)$ & $\%$ & & (m³/ha) & $\%$ \\
\hline 3 & 14555 & - & - & 15185 & - & - \\
\hline 6 & 12945 & 1610 & 11.06 & 12920 & 2265 & 14.92 \\
\hline 9 & 9340 & 5215 & 35.83 & 9295 & 5890 & 38.79 \\
\hline
\end{tabular}

TABLE 8. Effect of irrigation intervals and sulfur rates and their interactions on water productivity (kg grains / $\mathrm{m}^{3}$ water) during 2015 and 2016 seasons.

\begin{tabular}{lcccccccccc}
\hline \multirow{2}{*}{$\begin{array}{l}\text { Irrigation } \\
\text { intervals } \\
\text { (days) }\end{array}$} & \multicolumn{10}{c}{ 2015 season } \\
\cline { 2 - 13 } & $\mathbf{0}$ & $\mathbf{2 0 0}$ & $\mathbf{4 0 0}$ & $\mathbf{6 0 0}$ & Mean & $\mathbf{0}$ & $\mathbf{2 0 0}$ & $\mathbf{4 0 0}$ & $\mathbf{6 0 0}$ & Mean \\
\hline 3 & 0.245 & 0.272 & 0.312 & 0.299 & 0.282 & 0.239 & 0.271 & 0.317 & 0.306 & 0.283 \\
6 & 0.247 & 0.276 & 0.304 & 0.326 & 0.288 & 0.255 & 0.291 & 0.315 & 0.353 & 0.303 \\
9 & 0.195 & 0.244 & 0.268 & 0.334 & 0.260 & 0.209 & 0.264 & 0.335 & 0.391 & 0.300 \\
Mean & $\mathbf{0 . 2 2 9}$ & $\mathbf{0 . 2 6 4}$ & $\mathbf{0 . 2 9 5}$ & $\mathbf{0 . 3 2 0}$ & & $\mathbf{0 . 2 3 4}$ & $\mathbf{0 . 2 7 5}$ & $\mathbf{0 . 3 2 2}$ & $\mathbf{0 . 3 5 0}$ & \\
\hline
\end{tabular}




\section{Conclusion}

Finally, it can be concluded that shortest Irrigation interval (3 days) was more effective and increased most of growth characters and yield and its components studied. However, increasing irrigation intervals up to 9 days was unfavorable and decreased the grain productivity of rice, followed by irrigation interval every 6 days under salinity stress . Sulfur application significantly increased the ability of rice plants to tolerant the harmful effect of salinity and water stress together by decreasing the values of $\mathrm{EC}$, $\mathrm{pH}$ and bulk density which led to improve the soil chemical properties in this study . Moreover, sulfur application increased water productivity as well as improved growth parameters and yield of rice.

\section{References}

Ahmed, K., Qadir, G., Jami, A.R., Saqib, A.I., Nawaz, M.Q., Kamal, M.A. and Haq, E. (2016) Strategies for soil amelioration using sulphur in salt affected soil. Cercetari Agronomice in Moldova, 3 (167), 5-16.

Ali, R., Khan, M.J. and Khattak, R. A. (2008) Response of rice to different sources of sulphur (S) at various levels and its residual effect on wheat in rice-wheat cropping system. Soil Environ. 27,131 - 137.

Black, C.A., Evans, D.D., Ensminger, L.E., White, J.L. and Clark, F.E. (1965) "Methods of Soil Analysis". Amer. Soc . Agron. Inc. Pub., Madison, Wisc., U.S.A, pp. 383-390

Dobermann, A. and Fairhurst, T. (2000) "Rice Nutrient Disorder and Nutrient Management". Handbook Series. Potash and Phosphate Institute of Canadaand International Rice Research Institute, 191 pp.

Dubousset, L., Etienne, P. and Avice, J.C.(2010) Is the remobilization of $\mathrm{S}$ and $\mathrm{N}$ reserves for seed filling of winter oil seed rape modulated by sulphate restrictions occurring at different growth stages? J. Exp.Bot. 61 (15), 4313-4324.

Duncan, B. (1955). Multiple Range and Multiple F. test. Biometrics, 11, 1-42.

EL-Eweddy, E. A., Beheiry, G. Gh. and Alaga, M. D. (2005) The effect of elemental sulphur and synthetic soil conditions on some chemical properties and plant production of calcareous soils. Egyptian Journal of Applied Science, 20, 734-747.

El- Refaee, I.S., Gorgy, R.N. and Metwally, T.F. (2012) Response of some rice cultivars to plant spacing for improving grain yield and water productivity undet different irrigation intervals. Alex. J. Agric. Res. 57, (1), 1-15.
El-Sharkawy, H.M., Zayed, B. , Honna, T. and Yamamoto, S. (2006) Chemical compositions and salinity development in paddy soil as affected by irrigation intervals of mixed water under saline soil. Pak. J. Biol. Sci. 9(4),741-745.

Ghazy,. Hasnaa A. (2015) Response of rice crop to organic and mineral fertilization under different irrigation regimes .Ph.D. Thesis, Fac. of Agric., Kafr El-Sheikh, Univ, Egypt.

Gomez, K.A. and Gomez, K.S. (1984) "Statistical Procedures for Agricultural Research". $2^{\text {nd }}$ ed., John Wiley and Sons

Helmy, A.M., Shaban, KH.A. and EL-Galad, M.A. (2013) Effect of gypsum and sulphur application in amelioration of saline soil and enhancing rice productivity J.Soil Sci. and Agric. Eng., Mansoura Univ., 4 (10), 1037 - 1051.

Ibrahim, M.E., El-Shamarka, S.A., El-Refaee, I.S., Ali, O. A. M. and Sheta, I. A. (2017) Effect of irrigation intervals and organic and mineral fertilization systems on productivity and quality of hybrid rice

Khajeh-Hosseini, M., Powell, A.A. and Bimgham, I.J. (2003) The interaction between salinity stress and seed vigor during germination of soybean seeds. Seed Sci. Technol. 31,715-725.

Kineber, M.F.A., EL-Masry, A.A. and Gohar, M.N. (2004). Effect of sulphur application and nitrogen fertilization on yield and its quality for some flax varieties in alkaline soil. Annals of Agricultural Science, 49, 53-69.

Lunde, C., Simonsen, Z. A., Nielsen, H. T., Blennow, P. and Anna, A. H. (2008) Sulfur starvation in rice: The effect on photosynthesis, carbohydrate metabolism, and oxidative stress protective pathways. Physiologia Plantarum, 134(3), 521-508

Michael, A.M. (1978) "Irrigation Theory and Practice" (p. 110). Vikas Publishing House, PVT. Ltd. New Delhi,India

Mazhar, A.M.A., Mahgoub, H.M. , and Abd El-Aziz, G.N. (2011) Response of Schefflera arboricola L. to gypsum and sulphur application irrigated with different levels of saline water. Austr. J. Basic Appl. Sci. 5,121-129.

Muneer, S., Lee, B.R. , Kim, K.Y., , Park, S.H., , Zhang, Q. and Kim, T.H. (2014) Involvent of sulphur nutrition in modulating iron deficiency responses in photosynthetic organelles of oil seed rape (Brassica napus L.). Photosynth. Res. 119, 319 329.doi:10.1007/s11120-013-9953-8

Page, A.I., Miller, R.H. and Keeney, D.R. (1982) "Methods of Soil Analysis. Part 2: Chemical and 
Microbiological Properties". 2 nd ed., pp. 199-223, Agronomy monograph, No. 9, Amer. Soc . of Agron., Madison, Wisconsin, U.S.A.

Rang, Z., Jagadish, W., Zhou, S.V.K., Craufurd, Q.M. and Heuer, P.Q. (2011) Effect of high temperature and water stress on pollen germination and spikelet fertility in rice. Environmental and Experimental Botany, 70, 58-65

Yoshida, S. (1972) Physiological aspects of grain yield. Annu. Rev. Plant Physiol. 23, 437-464.

Zaman, B., Ali, A., Salim, M. and Niazi, B.H . (2002) Role of sulphur for potassium/sodium ratio in sunflower under saline conditions. Helia, 25 (37), 69-78.
Zayed, B.A., Saiad, I.A.El-,Bassiouni,S.M.and Salem, A.K.(2013) Effect of different planting systems on soil water and rice productivity in the northern part of Delta in Egypt. J. Soils Sci and Agric. Eng., Mansoura Univ.4(5), 453-462

Zeng, L. (2004) Response and correlated response to salt tolerance selection in rice by yield parameters. Cereal Research Communications, 32(4), 477-484.

Zhao, F. (1999) Sulphur assimilation and effects on yield and quality of wheat. J. Cereal Sci. 30, $1-5$.

Zhu, Z., Wei, G., Li, J., Qian, Q. and Yu, J. (2004) Silicon alleviates salt stress and increases antioxidant enzymes activity in leaves of salt-stressed cucumber (Cucumis sativus L.). Plant Sci. 167, 527-533.

\section{استجابة محصول الأرز لإضافة الكبريت تحت ظروف الإجهاد المائي والملحي \\ بسيوني عبد الرازق زايد ، محمد سيد محمود عبد العال "و جلال أحمد دويدار

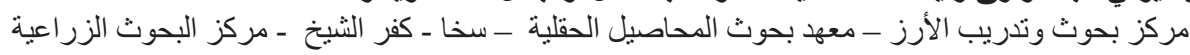 و وقسم المحاصيل - كلية الزراعة - جامعة المنوفية ـ شبين الكوم ـ مصر.}

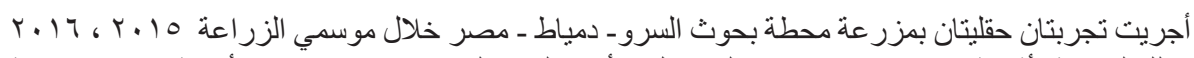

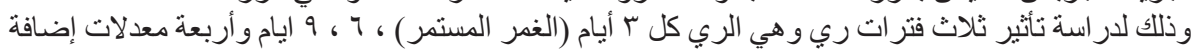

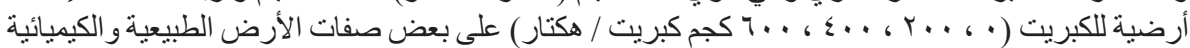

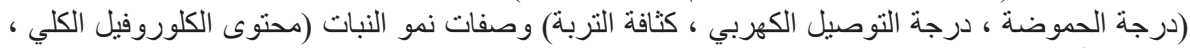

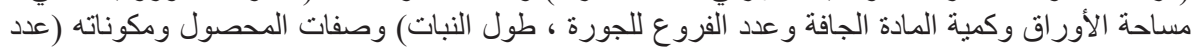

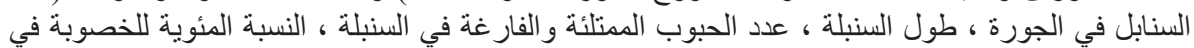

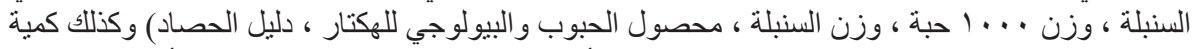

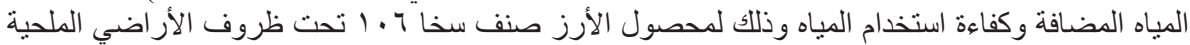

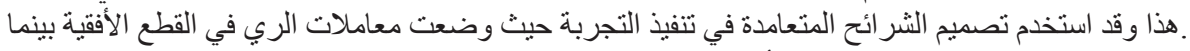

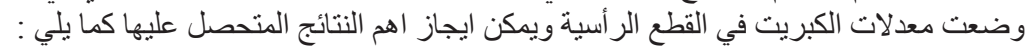

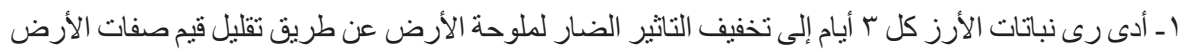

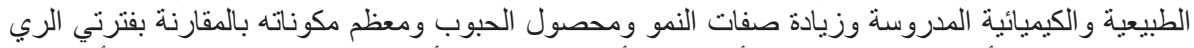

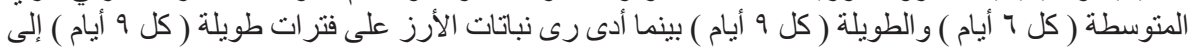
زيادة معنوية في عدد الحبوب الفار غلة في النة السنبلة

זـ أدت زيادة معدلات الكبريت المضافة حتى . . 7 كجم كبريت / هكتار إلي تقليل الأثر الضار لملوحة التربة

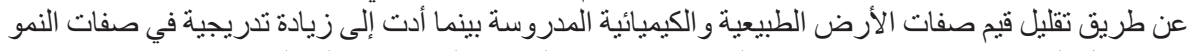

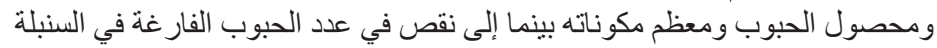

بـ تثنير نتائج التفاعل إلى زيادة إنتاجية محصول الحبوب و المحصول البيولوجي للاككتار وذللك باضافة الكبريت

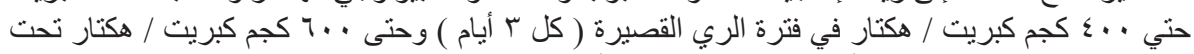
فترتي الري المتوسطة ( كل 1 أيام ) و الطويلة ( كل 9 أيام )

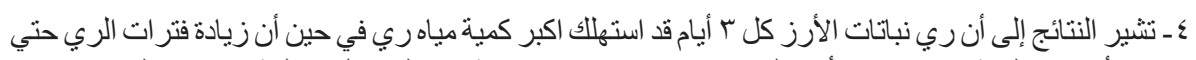

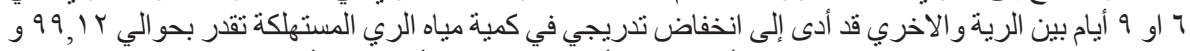

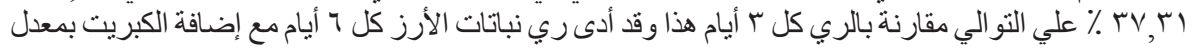

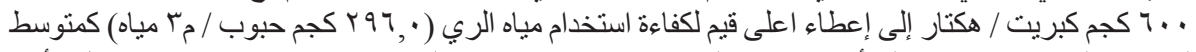

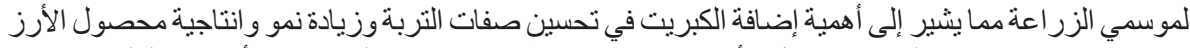
ورفع كفاءة استخدام مياه الري في حقول الأرز وخاصة تحت ظروف الكيرة الاجهاد المائي في الأر اضي الملحية 